\title{
Upaya Pencegahan Kecelakaan Kerja pada Praktikum Mengoperasikan Traktor 4 Roda 4 WD Menggunakan Metode Modifikasi Pedal Kopling
}

\author{
Erman $^{1}$ \\ 1Politeknik Negeri Lampung, Bandar lampung, Jl. Soekarno-Hatta Raja Basa No. 10 kode \\ pos 35144, E-mail: ermanst05@gmail.com, erman@polinela.ac.id,
}

Submisi: 24 Oktober 2020; Penerimaan: 25 November 2020

\begin{abstract}
ABSTRAK
Aspek perlindungan tenaga kerja yang diatur dalam Undang-Undang Nomor 13 Tahun 2003 menyatakan bahwa dengan menerapkan teknologi pengendalian keselamatan dan kesehatan kerja, diharapkan tenaga kerja akan mencapai ketahanan fisik, daya kerja dan tingkat kesehatan yang tinggi. Politeknik Negeri lampung, program studi mekanisasi pertanian salah satu peralatan praktikum menggunakan traktor 4 roda 4 WD yang pengoperasiannya beresiko tinggi yang dijadikan topik permasalahan pada kajian ini

Penelitian ini bertujuan untuk: 1)Mencegah kecelakaan kerja pada peraktikum mengoperasikan traktor 4 roda $4 W D$,2) Memodifikasi pedal kopling untuk mendapat kan tambahan pedal kopling yang pas untuk pendamping/pelatih (PLP) Penelitian ini menggunakan metode kualitatif dan pendekatan deskriptif , teknik utama mengumpulkan data yaitu observasi dan wawancara mendalam. Kecelakaan pada saat praktikum mengoperasikan traktor dapat di cegah/diminimalkan, dengan cara memodifikasi pedal kopling untuk pendamping (PLP). Pelaksanaan penelitian dilakukan di Laboratorium Logam dan Otomotif serta lapangan per kebunan Politeknik Negeri Lampung, pada jadwal praktikum, Kegiatan analisis dan wawancara mendalam di lakukan secara simultan sepanjang periode penelitian kurun waktu enam bulan (satu semester)

Hasil kajian dari simulasi pedal kopling yang belum dimodifikasi dengan yang sudah dimodifikasi dilapangan dan wawancara mendalam peneliti dengan responden menyatakan bahwa pedal kopling yang sudah dimodifikasi lebih aman dan nyaman di bandingkan pedal kopling yang belum dimodifikasi, Pendamping praktikum dapat langsung menekan pedal kopling apabila berpotensi insiden tanpa mengganggu dan menunggu mahasiswa selama praktikum, semua responden memberikan pernyataan yang sama.
\end{abstract}

Kata Kunci: Pencegahan kecelakaan kerja, Traktor 4 roda 4 WD, Pedal kopling, Peraktikum.

\section{PENDAHULUAN}

\section{Latar Belakang Masalah}

Keselamatan dan kesehatan kerja merupakan suatu pemikiran dan upaya untuk menjamin keutuhan dan kesempurnaan baik jasmani maupun rohani. Undang-Undang Nomor 13 Tahun 2003. Dengan menerapkan teknologi pengendalian keselamatan dan kesehatan kerja, diharapkan tenaga kerja akan mencapai ketahanan fisik, daya kerja dan tingkat kesehatan yang tinggi. .
Ada empat faktor penyebab kecelakaan kerja yaitu:

a. Faktor manusia, diantaranya kurangnya keterampilan atau pengetahuan tentang kesehatan dan keselamatan kerja

b. Faktor material atau peralatannya, misalnya bahan yang seharusnya dibuat dari besi dibuat dengan bahan lain yang lebih murah 
sehingga menyebabkan

kecelakaan kerja

c. Faktor sumber bahaya, meliputi:

- Perbuatan bahaya, misalnya metode kerja yang salah, sikap kerja yang teledor serta tidak memakai alat pelindung diri

- Kondisi/keadaan bahaya, misalnya lingkungan kerja yang tidak aman serta pekerjaan yang membahayakan

Faktor lingkungan kerja yang tidak sehat, misalnya kurangnya cahaya, ventilasi, pergantian udara yang tidak lancar dan suasana yang sumpek (Lalu Husni, 2003).

Demi meningkatkan produksi pertanian dan tuntutan teknologi yang semakin maju maka dalam proses budidaya tanaman sampai pasca panen harus dapat dikerjakan dalam waktu seefisien mungkin.

Mekanisasi Pertanian diartikan sebagai pengenalan dan penggunaan yang bersifat mekanis. Untuk melangsungkan operasi pertanian, bantuan yang bersifat mekanis tersebut termasuk semua jenis alat atau perlengkapan yang digerakkan oleh tenaga manusia, hewan, motor bakar, motor listrik, angin, air dan sumber energi lainnya. Salah satu alat atau perlengkapan yang digunakan dalam pelaksanaan pendidikan pada program studi mekanisasi pertanian jurusan Teknologi Pertanian Politeknik Negeri Lampung, dalam hal ini praktikum baik di Laboratorium maupun di kebun adalah Traktor pertanian 4 roda 4 WD sumber tenaga motor bakar diesel. Pengoperasian traktor pertanian 4 roda 4 WD sangat beresiko tinngi umumnya pada latihan dasar dikarnakan pelepasan pedal kopling dan penekanan pedal gas tidak seimbang, maka perlu pencegahan kecelakaan pada pemula saat praktikum mengoperasikan traktor.

Pada umumnya. Traktor tidak dilengkapi alat pencegahan kecelakaan dan pelindung diri didalam pengoperasian, sehingga tidak menutup kemungkinan hal ini dapat menimbulkan kecelakaan pada tahap pemula praktikum mengoperasikan.

Traktor 4 roda 4 WD dalam mengoperasikannya atau mengendarai sama dengan mobil yang dilengkapi dengan stir kemudi, pedal kopling, pedal gas, tuas perseneling dan pedal rem sebagai pengendali arah dengan operator duduk. Berbeda dengan traktor tangan operator ikut berjalan dengan memegang handel stang. Traktor adalah kendaraan yang didesain secara spesifik untuk keperluan traksi tinggi pada kecepatan rendah, atau untuk menarik trailer atau implemen yang digunakan dalam pertanian.

Cara memberhentikan traktor 4 roda 4 WD yang harus dilakukan pertama kali adalah menekan pedal kopling, lalu menekan pedal rem, sehingga perlu penambahan dimensi pedal kopling untuk pelatih agar dapat lansung menekan pedal kopling tanpa menggangu dan menunggu mahasiswa praktikum ketika dalam keadan bahaya.

\section{Rumusan Masalah}

Berdasarkan latar belakang yang dikemukakan sebelumnya, maka beberapa masalah yang akan dirumuskan dalam makalah ini adalah :

Traktor 4 roda 4 WD diciptakan untuk industri pertanian bukan untuk pendidikan dan pelatihan, sehingga alat tersebut tidak dilengkapi alat pencegahan kecelakaan. Dan ini yang harus kita pikirkan bersama untuk memberikan solusi bagai - mana, mencegah kecelakaan pada praktikum mengoperasian traktor 4 roda 4 WD yang umumnya diakibatkan karena melepas pedal kopling dengan penekanan pedal 
gas / akselerasi tidak seimbang khususnya pada praktikum dasar mengoperasikan traktor 4 roda 4 WD.

\section{Tujuan penelitian}

Tujuan yang ingin dicapai pada penelitian ini adalah sebagai berikut:

1. Mencegah kecelakaan kerja pada praktikum dasar mengoperasikan Traktor 4 roda 4 WD

2. Memodifikasi pedal kopling untuk mendapat kan tambahan pedal kopling yang pas untuk pendamping/pelatih (PLP).

\section{Kegunaan Penelitian}

Manfaat / kegunaan yang diharapkan dalam Penelitian ini:

1. Pada saat praktikum. PLP dan mahasiswa merasa betah, nyaman, aman, dan selamat dari gangguan kecelakaan pada saat praktikum mengoperasikan traktor.

2. Proses belajar dan mengajar/praktikum pada mata kuliah Traktor Pertanian tercapai dengan sebaik baiknya.

\section{METODE PENELITIAN}

\section{Waktu dan Lokasi Penelitian}

Penelitian dilaksanakan di laboratorium Logam dan Otomotif dan area perkebunan, sedang latihan pengoperasian traktor di jalan area perkebunan yang merupakan lokasi praktikum Politeknik Negeri Lampung.

Alat

Alat yang digunakan terdiri dari:

1. Mesin las

2. Mesin Milling

3. Mesin gerinda Portable

4. Mesin gerinda duduk

5. Toollset

6. Mesin gergaji

7. Gergaji tangan

8. Palu

\section{Bahan}

Bahan yang di gunakan:

1. Pelat tebal $2 \mathrm{~cm} \times 50 \mathrm{~cm} \times 20 \mathrm{~cm}$

2. Pelat bordes tebal $5 \mathrm{~mm}$ $\mathrm{x} 15 \mathrm{~cm} \times 10 \mathrm{~cm}$

3. Kawat las $\mathrm{Rb} 26$

4. Gas LPG

5. Gas Oksigen

6. Baut dan mur

\section{Metode kajian}

Penelitian ini menggunakan metode kualitatif dan pendekatan deskriptif. Metode Kualitatif sering disebut metode penelitian naturalistik, karena penelitiannya dilakukan pada kondisi yang alamiah (natural setting) (Sugiyono, 2009). Responden dalam kajian ini peneliti memanfaatkan teman sejawat (PLP) dan mahasiswa peserta praktikum.

\section{Rancangan Desain Alat}

Rancangan dan Desain alat menyesuaikan yang ada pada traktor, baik bentuk dan dimensinya yaitu panjang $12 \mathrm{~cm}$ dan lebar $7 \mathrm{~cm}$

\section{Proses Pembuatan alat}

Proses pembuatan alat yang dilakukan antara lain:

1. Membuat tapakan pedal kopling: Plat bordes dipotong menggunakan brander potong dengan ukuran panjang $12 \mathrm{~cm}$ dan lebar $7 \mathrm{~cm}$. Untuk tapakan pedal

2. Membuat tuas penyangga tapakan pedal kopling: Plat tebal $2 \mathrm{~cm} \times 50 \mathrm{~cm} \times 20 \mathrm{~cm} \quad$ dipotong menggunakan brander potong menyesuaikan bentuk lengkung dan ukuran tuas penyangga pedal yang ada pada traktor, hal ini setiap traktor berbeda-beda baik bentuk maupun dimensinya tergantung pada sfesifikasi traktor

3. Langkah ketiga setelah tapakan dan tuas penyangga pedal kopling 
terbetuk dirakit/disatukan menggunakan las listrik

4. Langkah selanjutnya pedal kopling dan tuas dipasang pada tuas kopling traktor menggunakan 2 buah baut/mur $14 \mathrm{~mm}$

5. Alat dapat dilepas apa bila traktor tidak digunakan untuk latihan

\section{HASIL DAN PEMBAHASAN}

Peneliti akan memaparkan fokeus dari penelitian ini yaitu Upaya Pencegahan Kecelakaan Pada Praktikum Mengoperasikan Traktor 4 roda 4 WD Dengan Metode Modifikasi Pedal Kopling.

Penelitian ini menggunakan metode kualitatif dan pendekatan deskriptif. Metode Kualitatif sering disebut metode penelitian naturalistik karena penelitiannya dilakukan pada kondisi yang alamiah (natural setting) (Sugiyono, 2009).

Pada penelitian kualitatif peneliti dituntut dapat menggali data berdasarkan apa yang diucapkan, dirasakan, dan dilakukan oleh sumber data. Pada penelitian kualitatif, peneliti berdasarkan sebagai mana adanya yang terjadi di lapangan, yang dialami, dirasakan, dan dipikirkan oleh sumber data.

Dengan melakukan penelitian melalui pendekatan deskriptif maka peneliti harus memaparkan, menjelaskan, menggambarkan data yang telah diperoleh oleh peneliti melalui wawancara mendalam yang dilakukan dengan para responden, dalam hal ini adalah pranata laboratorium pendidikan (PLP), dan mahaasiswa yang sedang melakukan kegitan praktikum mengopersaikan Traktor 4 roda 4 WD dan simulasi menggunakan Pedal kopling yang sudah dimodifikasi dan yang belum dimodifikasi.
Pada bab ini dibagi menjadi tiga bagian, agar lebih sistimatis dan terarah yaitu sebagai berikut:

1. Deskripsi responden peneliti

2. Simulasi alat sesudah dan sebelum dimodifikasi, deskripsi hasil penelitian

3. Pembahasan

\section{Deskripsi Responden penelitian Semua responden dalam penelitian ini adalah Pranata Laboratorium Pendidikan (PLP) Program studi mekanisasi pertanian Politeknik Negeri Lampung dan mahasiswa Politeknik Negeri Lampung yang sedang melaksanakan Praktikum mengoperasikan traktor 4 roda 4WD, dan tidak merasa keberatan untuk disebutkan namanya, pekerjaannya dan karakternya, adapun responden penelitian ini disajikan pada tabel 1 .}

\section{Simulasi Pedal kopling yang sudah dimodifikasi}

Hasil modifikasi/penambahan pedal kopling untuk pelatih dapat dilihat pada Gambar 1 dan Gambar 2. Simulasi penggunaan kopling yang telah dimodifikasi dapat dilihat pada Gambar 3.

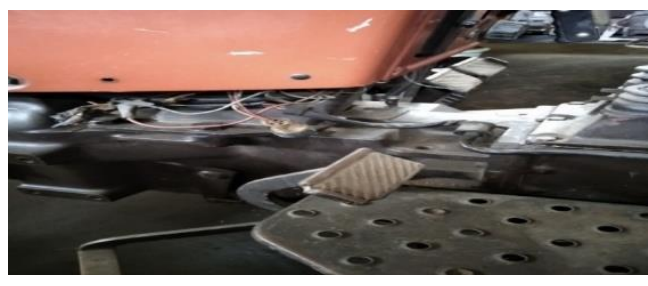

Gambar 1: Pedal kopling sebelum dimodifikasi

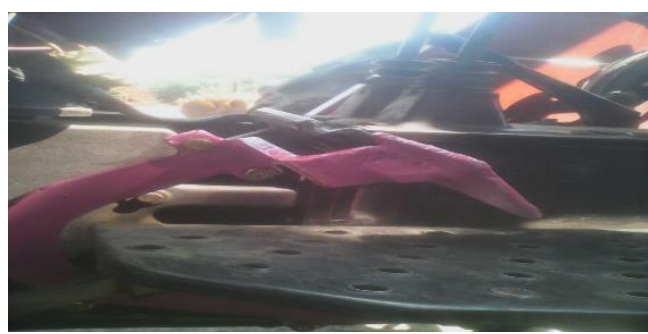

Gambar 2: Pedal kopling sesudah dimodifikasi 
Tabel 1: Deskripsi Responden

\begin{tabular}{|c|c|c|c|}
\hline No. & $\begin{array}{c}\text { Nama } \\
\text { Responden }\end{array}$ & Pekerjaan & Catatan \\
\hline 1 & $\begin{array}{c}\text { Bpk. } \\
\text { A.Sulasin }\end{array}$ & PLP & $\begin{array}{l}\text { Bpk. A. Sulasin beliau adalah PLP. Mekanisasi pertanian } \\
\text { Politeknik Negeri Lampung Yang mendampingi mahasiswa } \\
\text { praktikum mengoperasikan traktor } 4 \text { roda } 4 \text { WD, peneliti } \\
\text { dan responden sudah lama kenal dengan beliau semenjak } \\
\text { sama-sama jadi PLP. Beliau bersedia membantu peneliti } \\
\text { untuk memberikan data-data yang akurat. }\end{array}$ \\
\hline 2 & $\begin{array}{l}\text { Bpk. M. } \\
\text { Yusfiar } \\
\text { Karfiandi, } \\
\text { A.Md. }\end{array}$ & PLP & $\begin{array}{l}\text { Bpk. M. Yusfiar Karfiandi, A.Md. beliau adalah PLP. } \\
\text { Mekanisasi Pertanian dan sekali gus penanggung jawab } \\
\text { traktor } 4 \text { roda } 4 \text { WD Politeknik Negeri Lampung, peneliti tau } \\
\text { betul krakter beliau yaitu obyektif dan konsisten. } \\
\text { Mas Solihin mahasiswa semester } 3 \text { program studi D4 } \\
\text { Teknologi Perbenihan Jurusan Budidaya Tanaman }\end{array}$ \\
\hline 3 & Mas Solihin & Mahasiswa & $\begin{array}{c}\text { Pangan, beliau merupakan sosok yang cerdas serta sudah } \\
\text { terampil dalam mengoperasikan traktor } 4 \text { roda } 4 \text { WD dan } \\
\text { bersedia menjadi pelatih praktikum } \\
\text { Mas Joko mahasiswa semester } 3 \text { program studi D4 } \\
\text { Teknologi Perbenihan Jurusan Budidaya Tanaman }\end{array}$ \\
\hline 4 & Mas Joko & Mahasiswa & $\begin{array}{c}\text { Pangan, beliau sudah terampil dalam mengoperasikan } \\
\text { traktor } 4 \text { roda } 4 \text { WD dan bersedia menjadi pelatih } \\
\text { praktikum } \\
\text { Mas Budi mahasiswa semester } 3 \text { program studi D4 } \\
\text { Teknologi Perbenihan Jurusan Budidaya Tanaman }\end{array}$ \\
\hline 5 & Mas Budi & Mahasiswa & $\begin{array}{c}\text { Pangan, beliau merupakan sosk yang mudah bergaul, } \\
\text { ramah dan sudah terampil dalam mengoperasikan traktor } 4 \\
\text { roda } 4 \text { WD dan bersedia menjadi pelatih praktikum sekali } \\
\text { gus diwawancarai }\end{array}$ \\
\hline
\end{tabular}

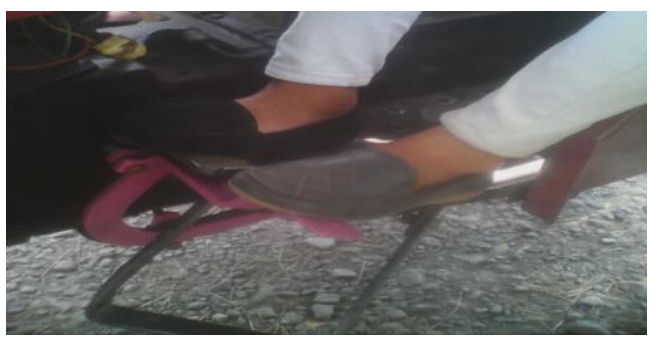

Gambar 3: Simulasi pedal kopling yang sudah dimodifikasi, pelatih dan mahasiwa praktikum mengoperasikan traktor 4 roda 4 WD.

Sebagai upaya pencegahan kecelakaan kerja di simulasikan pelatih beserta mahasiswa praktikum mengoperasikan traktor 4 roda 4 WD berlangsung. Dalam hal praktikum ini, pelatih dan mahasiswa merasa aman dan nyaman, umum pada saat pelepasan pedal kopling tidak seirama dengan menginjak tuas gas/akselerasi sehingga traktor berpotensi loncat. Dengan adanya pedal kopling tambahan untuk pelatih secara otomatis pelatih dapat membantu irama pelepasan pedal kopling, dan menginjak pedal kopling untuk memberhentikan traktor tanpa harus menginjak kaki dan pedal kopling yang mahasiswa gunakan saat darurat. Seperti terlihat pada gambar 3 pelatih dapat menginjak pedal kopling dalam keadaan darurat tanpa harus menginjak injak pedal kopling dan kaki mahasiswa peserta latihan. Gambar 3

\section{Simulasi Pedal kopling yang belum dimodifikasi dan pembahasan;}

Tahap berikutnya simulasi pedal kopling yang belum dimodifikasi. Pelatih dan peseta praktikum pada saat praktikum mengoperasikan traktor 4 roda 4 WD umumnya pedal kopling traktor dalam penekanannya lebih berat dibandingkan dengan mobil, sehingga penekan pedal kopling tidak penuh dan pelepasan pedal kopling untuk pemula kurang stabil, dalam hal ini pelatih tidak dapat membantu menginjak pedal kopling traktor 4 roda 4 WD karena 
pelatih tidak memiliki pedal kopling, sehingga harus menginjak kaki mahasiswa praktikum.

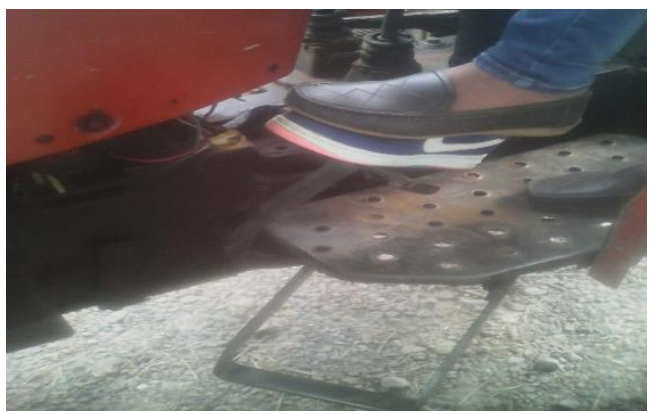

Gambar 4: Pedal kopling yang belum di modifikasi pelatih beserta mahasiwa praktikum mengoperasikan traktor 4 roda 4WD.

Terlihat pada gambar 4 dimana kaki mahasiswa peserta praktikum terinjak oleh pelatih saat pelatih menghentikan traktor secara tiba-tiba, hal ini membuat peserta praktikum dan pelatih tidak nyaman. Gambar 4 diatas

\section{Deskripsi Hasil Penelitian/simulasi}

Data hasil penelitian didapatkan melalui wawancara mendalam peneliti dengan responden setelah alat di simulasikan baik pada pedal kopling yang sudah dimodifikasi maupun yang belum dimodifikasi kurun waktu satu semester. Dimana seluruh responden yang diwawancara mendalam adalah Pranata Laboratorium Pendidikan (PLP). Dan Mahasiswa yang sedang melakukan praktikum mengoperasikan traktor 4 roda 4 WD di lahan perkebunan Politeknik Negeri lampung. Diperoleh hasil yang serupa antar jawaban yang satu dengan jawaban lainnya dari masing-masing responden.

\section{Wawancara mendalam}

1. Peneliti: apakah pedal kopling yang belum dimodifikasi dan yang sudah dimodifikasi bermanfaat?

Responden: mengatakan sangat bermanfaat dengan adanya pedal kopling tambahan, pelatih dapat membantu menginjak pedal kopling saat tuas gigi perseneling dikondisikan dan pelepasan kopling ketika traktor dijalankan

2. Peneliti: Apakah pedal kopling tambahan/modifikasi dapat berupaya mencegah kecelakaan

Responden: Dapat, dengan tersedianya tambahan pedal kopling pelatih/pendamping praktikum dapat memberhentikan laju traktor, jika dalam keadaan darurat tanpa menunggu dan mengganggu/menginjak kaki mahasiswa praktikum mengeoperasikan

\section{Penentuan skor jawaban}

Skor jawaban merupakan nilai jawaban yang diberikan oleh responden.

Tabel 2. Skor jawaban responden

\begin{tabular}{cc}
\hline Skala jawaban & Nilai \\
\hline Sangat Tidak Setuju (STS) & 4 \\
Kurang Setuju (KS) & 8 \\
Cukup Setuju (CS) & 12 \\
Setuju (S) & 16 \\
Sangat Setuju (SS) & 20 \\
\hline
\end{tabular}

\section{Skor Ideal}

Tabel 3. Skor Ideal

\begin{tabular}{cc}
\hline Rumus & skala \\
\hline Nilai skala $\times$ responden $=20 \times 5=$ & SS \\
100 & \\
Nilai skala $\times \begin{array}{r}\text { responden }=16 \times 5= \\
80\end{array}$ & $\mathrm{~S}$ \\
Nilai skala $\times \begin{array}{r}\text { responden }=12 \times 5= \\
60\end{array}$ & $\mathrm{CS}$ \\
Nilai &
\end{tabular}

Nilai skala $\times$ responden $=8 \times 5=40 \quad \mathrm{KS}$

Nilai skala $x$ responden $=4 \times 5=20$ SKS

Skor ideal merupakan skor yang digunakan untuk menghitung atau menentukan skala dan jumlah seluruh jawaban dari kelima responden.

\section{Pemberian bobot}

Dari hasil wawancara mendalam peneliti dengan responden pada simulasi pedal kopling sebelum dan sesudah dimodifikasi kelima responden memberikan jawaban yang sama yaitu 
sangat setuju (SS) pedal kopling dimodifikasi untuk pelatih praktikum.

Sehingga total skor/bobot: Sangat setuju $\mathrm{x}$ jumlah responden $=100 \times 5=$ 500

\section{Persentase}

Langkah terakhir menghitung persetase dengan menggunakan Rumus adalah perbandingan total skor/bobot dengan total skor maksimum dikali $100 \%$ Sedangkan rumus skor maksimum adalah jumlah responden $\mathrm{x}$ skor tertinggi. Dimana skor tertinggi karna kelima responden memiliki jawaban yang sama, maka $=5 \times 100=500$. Indek persentase $=500: 500 \times 100 \%=100 \%$. Sehingga hasil wawancara dan diskusi jawaban kelima responden sama, peneliti menyatakan persentasenya adalah = $100 \%$ (seratus persen)

\section{PENUTUP}

\section{Kesimpulan}

Dari hasil kajian, diskusi dan pembahasan yang telah dilaksanakan atau dilakukan peneliti dapat menyimpulkan:

1. Pedal kopling yang sudah ditambah/dimodifikasi pelatih (PLP) dapat membantu pelepasan kopling pada praktikum dasar, untuk menghindari loncatan traktor 4 roda 4 WD dikarnakan melepas pedal kopling mendadak, dan memberhentikan traktor tanpa menunggu mahasiswa praktikum, sehingga dapat mencegah kecelakaan kerja.

2. Pedal kopling yang sudah ditambah/dimodifikasi pas / cocok untuk pelatih (PLP), sehingga pelatih dapat bertindak cepat menghentikan traktor 4 roda 4 WD, dalam keadaan darurat sebagai upaya pencegahan kecelakaan kerja tanpa menunggu peserta praktikum

\section{Saran}

1. Saat mengkondisikan dan menetralkan gigi tranmisi, kopling harus ditekan penuh, mintalah bantuan pelatih untuk menekan pedal kopling jika tidak kuat.

2. Untuk memberhentikan traktor, menambah kecepatan dan mengurangi kecepatan yang selalu diperhatikan adalah penekanan pedal kopling traktor pada posisi full, Penekanan pedal kopling tidak full/setengah kopling hal ini dapat merusak gigi atau gear teranmisi dan kanpas kopling.

\section{DAFTAR PUSTAKA}

Darwias Rasyid, MS. 1991. Peralatan produksi tradisional dan perkembangannya, Direktorat Pendidikan dan Kebudayaan, Ujung Pandang, Sulawesi Selatan.

Govil, AK dan Arsjad, 1983. Perawatan dan ilmu pengolahan lahan. Adira Yogyakarta

Husni, Lalu. 2003. Hukum Ketenaga kerjaan Indonesia. Jakarta: PT Raja Grafindo Persada.

Markkanen, Pia K. 2004. Kesehatan dan Keselamatan Kerja di Indonesia. Jakarta : Internasional Labour Organisation Sub Regional SouthEast Asia and The Pacific Manila Philippines

Sugiyono. 2009. Metode penelitian kualitatif. Bandung: Alfabeta

Suharto, 1991. Manajemen Perawatan Mesin. PT. Rieneka Cipta. Jakarta.

Sujoko, 1980. Perawatan dan Perbaikan Motor Diesel. Bumi Aksara, Bandung.

Suma'mur. 1981. Keselamatan Kerja dan Pencegahan Kecelakaan. Jakarta: Gunung Agung.

Sutrisno dan Kusmawan Ruswandi. 2007. Prosedur Keamanan, Keselamatan, \& Kesehatan Kerja. Sukabumi: Yudhistira.

Wijayanto, 1996. Memilih, Menggunakan dan merawat Traktor. Penebar Swadaya. Jakarta. 